Editors' Note: Oral medications for multiple sclerosis (MS), such as fingolimod, are an attractive alternative to injectable treatments. But postmarketing, potentially dangerous adverse effects such as the one reported below by Kinney and earlier by Visser et al. may help physicians and their patients plan the best treatment option for the patient's disease. In subSaharan Africa, there is an urgent need for optimizing preventive interventions for stroke (e.g., education and lowering prevalence of hypertension). Goldstein provides scientific proof for Chin's personal experience after visiting Mulago Hospital in Uganda.

Chafic Karam, MD, and Robert C. Griggs, MD

\section{TUMEFACTIVE MULTIPLE SCLEROSIS LESIONS UNDER FINGOLIMOD TREATMENT}

Michael O. Kinney, Gavin McDonnell, Belfast:

We would like to add our experience to the case reported by Visser et al. ${ }^{1}$

We diagnosed a 28-year-old woman with MS based on imaging, CSF, and oligoclonal bands. Treatment with glatiramer acetate (Copaxone) was initiated and continued for 6 years. She had clinically quiescent disease until April 2012, when she developed visual disturbance, ataxia, word-finding difficulties, poor concentration, and right hemisensory disturbance. Copaxone was stopped due to injection fatigue and with the intention of initiating fingolimod.

By the end of April, she had worsening ataxia, dyspraxia, and bilateral extensor plantars. IV methylprednisolone helped and she began treatment with fingolimod in May 2012. One month later, she had continence, speech, and cognitive difficulties, dyspraxia, ataxia, and right homonymous hemianopia. Fingolimod was stopped. MRI demonstrated extensive periventricular, callosal, and cerebral peduncle load with evidence of diffusion restriction consistent with late development of tumoral MS.

In clinical trials, fingolimod was used when the disease course was stable. ${ }^{2}$ In our case, it was used during active disease. It was temporally associated with a worsening of the clinical condition culminating in tumefactive MS several years after initial disease onset. We advocate a cautious approach in using novel immunomodulatory drugs.
Author Response: Mike P. Wattjes, Femke Visser, Bob W. van Oosten, Amsterdam: We read the clinical observation by Kinney et al., who described a patient presenting with tumefactive demyelinating lesions 1 month after the initiation of fingolimod therapy for MS. This observation confirms other case reports documenting the occurrence of atypical (tumefactive) demyelination ${ }^{1}$ and multifocal inflammatory disease progression in patients with MS treated with fingolimod. ${ }^{-4}$ Disease progression might be initiated by a switch from natalizumab to fingolimod in some cases, ${ }^{3,4}$ but also occurs in other situations, typically in the early stage of fingolimod treatment. ${ }^{1,2}$ These observations highlight that clinical and radiologic monitoring of patients with MS treated with the new generation of immunomodulative and immunosuppressive drugs goes beyond the early detection of possible opportunistic infections such as progressive multifocal leukoencephalopathy. Disease exacerbation and progression as a consequence of treatment failure or (unknown) side effects can also have negative consequences for the patient's prognosis. Although phase II and III studies have shown that fingolimod has a rather low and calculable risk profile, we caution that long-term experience is limited, which should alert us to any safety issues concerning opportunistic infections and beyond.

(C) 2013 American Academy of Neurology

1. Visser F, Wattjes MP, Pouwels PJ, Linssen WH, van Oosten BW. Tumefactive multiple sclerosis lesions under fingolimod treatment. Neurology 2012;79:2000-2002.

2. Castrop F, Kowarik MC, Albrecht H, et al. Severe multiple sclerosis: relapse under fingolimod therapy: incident or coincidence. Neurology 2012;78:928-930.

3. Jander S, Turowski B, Kieseier BC, Hartung HP. Emerging tumefactive multiple sclerosis after switching therapy from natalizumab to fingolimod. Mult Scler 2012;18:1650-1652.

4. Centonze D, Rossi S, Rinaldi F, Gallo P. Severe relapses under fingolimod treatment prescribed after natalizumab. Neurology 2012;79:2004-2005.

STROKE IN SUB-SAHARAN AFRICA: AN URGENT CALL FOR PREVENTION

Larry B. Goldstein, Durham, NC: In his Global Perspectives article, Dr. Chin ${ }^{1}$ reported on the resource constraints related to the provision of stroke 


\section{Neurology}

\section{Tumefactive multiple sclerosis lesions under fingolimod treatment \\ Michael O. Kinney, Mike P. Wattjes, Gavin McDonnell, et al. \\ Neurology 2013;81;403 \\ DOI 10.1212/WNL.0b013e31829deeb4}

This information is current as of July 22, 2013

\section{Updated Information \& Services}

References

Permissions \& Licensing

Reprints including high resolution figures, can be found at: http://n.neurology.org/content/81/4/403.1.full

This article cites 4 articles, 3 of which you can access for free at: http://n.neurology.org/content/81/4/403.1.full\#ref-list-1

Information about reproducing this article in parts (figures,tables) or in its entirety can be found online at:

http://www.neurology.org/about/about_the_journal\#permissions

Information about ordering reprints can be found online:

http://n.neurology.org/subscribers/advertise

Neurology ${ }^{\circledR}$ is the official journal of the American Academy of Neurology. Published continuously since 1951, it is now a weekly with 48 issues per year. Copyright (O) 2013 American Academy of Neurology. All rights reserved. Print ISSN: 0028-3878. Online ISSN: 1526-632X.

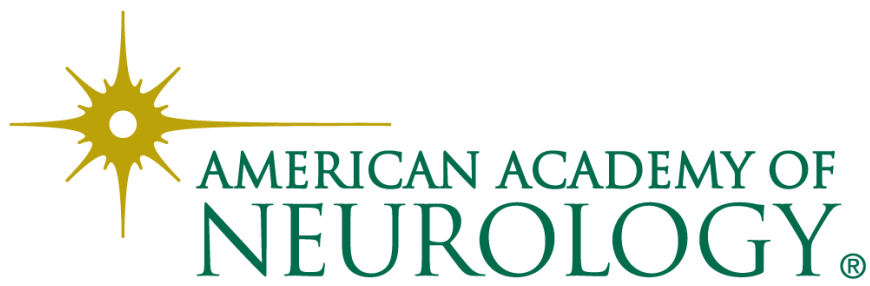

